\title{
40年間存在した側頭部爆弾異物症例
}

\author{
斎藤 秀樹・河村 正三・市川銀一郎 \\ 西谷 全弘・荻原徹
}

\section{Fragment of Bomb Removed after 40 Years; A Case Report}

\begin{abstract}
Hideki Saito, Shouzo Kawamura, Ginichiro Ichikawa, Masahiko Nishiya and Tooru Ogiwara
\end{abstract}

(Juntendo University)

A foreign body located in the right postauricular area was removed 40 years after a shrapnel injury in 1943. The patient visited our clinic complaining of pain behind his right ear. X-ray examination showed a dense foreign body located extracranially adjacent to the S.C.M.

Under general anesthesia an iron fragment was removed.

Key words: foreign body, bomb, postauricular area

緒言

異物は耳鼻咽喉科領域で必ずしも稀なもので はないがそのほとんどは短期間のうちに摘出さ れ，長期に残存するあのは比較的珍しいといえ る. 最近我々は約 40 年間耳後部に存在した銃弾 異物を経験したので報告する.

\section{症例}

72歳, 男性.

現病歴：

昭和18年，空襲にて全身に爆弾の破片を受 けた。

昭和30年頃右耳後部に腫脹出現するも疼痛 なきため放置.

昭和61年 12 月耳後部の疼痛出現, 徐々に増 悪.

昭和 61 年 12 月 10 日当院耳鼻科外来初診.
昭和61年12月16日手術目的にて入院.

既往歷 :

昭和 29 年肺結核にて肺部分切除.

昭和55年前立腺肥大にて切除術.

昭和56年甪径ヘルニアにて整復術.

家族歴：特記すべきととなし。

\section{入院時現象}

体格中等度, 栄養状態良, WBC: $6100, \mathrm{RBC}$ : $491 \times 10^{4}$, Hb: 14. 8, Hct: 44. 9, 血沈值 : 18/37, その他, 肝機能, 腎機能, 電解質等異常なし.

入院時, 右耳後部に約 $30 \mathrm{~mm} \times 30 \mathrm{~mm}$ の隆 起性病変を認めた（図１）。創部の皮虚は変色・ 硬化して抢り，一部に膿瘍形成がみられた。 そ の前縁は自潰し，ゾンデにて約 $5 \mathrm{~cm}$ 搟入され る. 自潰した部分からは黄白色粘液性の膿汁が 排出しており, 細菌培養では黄色ぶどう球菌, 
表皮ぶどう球菌，プロテウス等が検出された.

単純X線所見 : 右乳様突起のやや後方に非透 過性の陰影が確認でき（図2）, 断層撮影でも耳 後部の頭盍外隆起性病変の中に異物が認められ た. 乳突蜂巣内もやや陰影増強しており, 被弾 による戦傷が一部側頭骨にも及んだ事が示唆さ

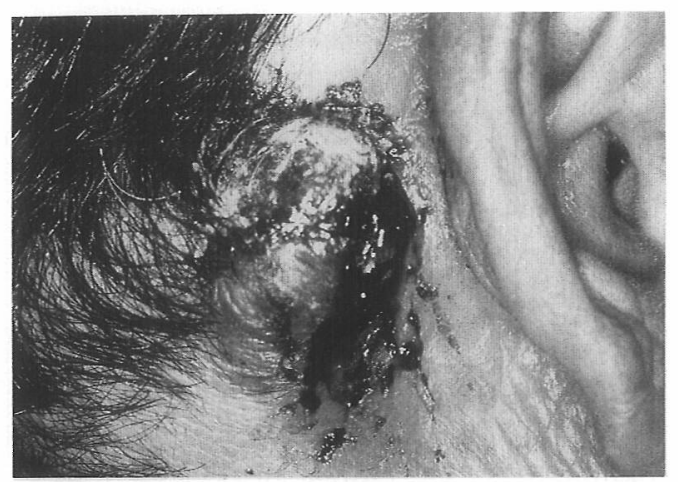

図1 来院時局所写真

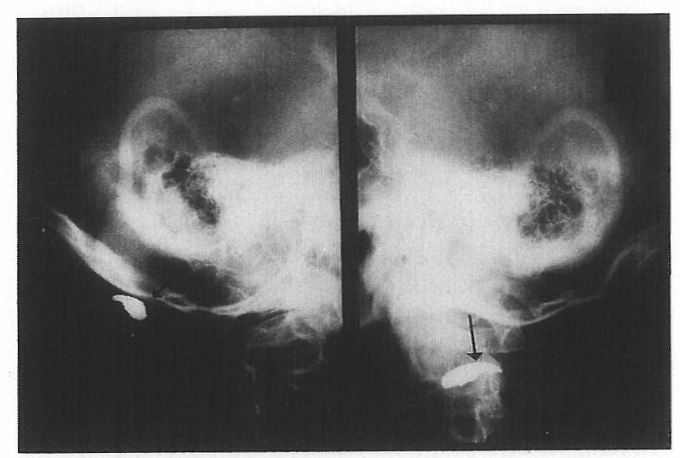

図 2 来院時単純X線写真

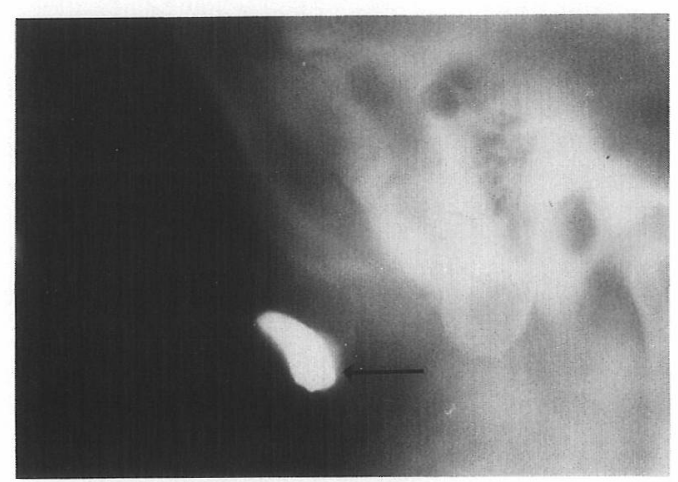

図 3 側頭部断層撮影

\section{れる(図 3 ).}

CT 所見：耳後部に高吸収域を呈する部分を 認め中心部よりアーチファクトが放射状に抗こ っており，異物はかなり硬いあのと推測された (図 4).乙れらの㭘査所見より 40 年前の爆弾片 が耳後部残存しており, それに炎症性变化が 伴ったものと考え全麻下に手術を行った。

\section{手術所見}

自潰した部分を含むように耳後部に紡錘形に 切開をいれた。直視野に中に異物を含んでいる 硬い肉芽組織を確認した。その周囲にも細かい 破片が存在し, 肉芽組織とともに異物を摘出し た（四 5 ).

摘出標本は約 $10 \mathrm{~mm} \times 20 \mathrm{~mm}$ の鉄の破片で 腐食し非常に脆い状態であった。

摘出術後経過良好にて第 8 病日に退院に至っ た。その後経過も順調である。

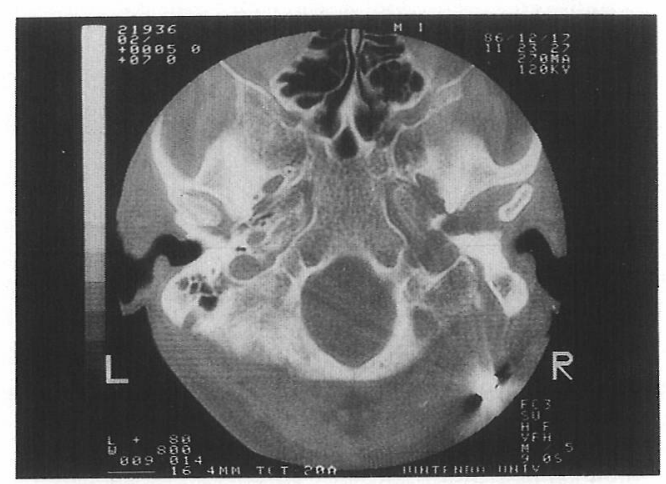

図 4 CT

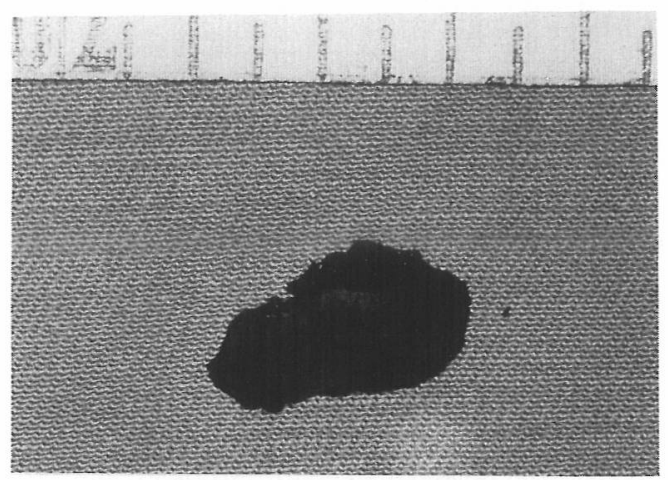

図 5 摘出された爆弾破片 
考 按

最近では頭頸部領域の銃，砲弾異物の報告は 稀であるが 1960 年代頃迄は，数多くの報告が ある. 代表的なところでは1957年城所らは30 例 ${ }^{1)} ， 1962$ 年森満らは53例2)，1963年太田らは 47 例 ${ }^{3)}$ の統計報告をしている（表 1 ). これら の報告では性，年齢，滞留期間，滞留部位，症 状などに差異は認めない。特に滞留期間に関し ては疾患の性質上からか 1 力月以内にはほとん どの例が排出，摘出されている． 3 年以上の長 期滞留例は我々が検索しえた範囲では1957年に 城所らが21年の例を，1985年に森川ら ${ }^{4)}$ が39年 の例を報告しているのみである，城所らの例は 空気銃で撃たれた鉛弾が眼窩内に滞留し21年後 に複視等の症状で発病した例でこの複視は鉛中 毒によるあのであろうと述べている.

本症例に最も近いのは森川らの報告例であり 戦時下に鉄の砲弾の破片を浴び耳下部に滞留し たその破片が39年後に疼痛などの症状を出現さ せたものである。長期滞留には様々な原因が考 えられるが滞留中ほとんど症状がないとと, 戦 時下などの特殊な状況下にあったこと, 摘出困 難な部位に存在したことなどが推測される。

異物の摘出の適応亡時期に関しては城所は患 者が苦痛を訴えず，副作用あなく，また手術を 希望していなければ放置しておいてもよいが鉛 中毒防止のため，また異物があるということに 対する患者の不安を除くため，摘出の操作が患

表 1 性, 年齢, 滞留期間, 滞留部位の文献的比較

\begin{tabular}{|c|c|c|c|}
\hline & $\begin{array}{c}\text { 森 満 ら } \\
(1962)\end{array}$ & $\begin{array}{c}\text { 城 所 ら } \\
\text { (1957) }\end{array}$ & 太田 ら \\
\hline 性 & 男:女 $=3: 1$ & 23/27が男 & 32/45が男 \\
\hline 齢 & $\begin{array}{l}20 \text { 歳以下が } \\
78 \%\end{array}$ & $\begin{array}{l}\text { 20歳以下が } \\
22 / 30\end{array}$ & $\begin{array}{l}\text { 20歳以下が } \\
\text { 過半数 }\end{array}$ \\
\hline 帯留期間 & $\begin{array}{l}1 \text { 力月以内は } \\
83 \%\end{array}$ & $\begin{array}{l}10 \text { 日以内が } \\
\text { 過半数 }\end{array}$ & $\begin{array}{l}10 \text { 日以内が } \\
\text { 過半数 }\end{array}$ \\
\hline 滞留部位 & $\begin{array}{l}\text { 副鼻腔 : } 29 \\
\text { 鼻腔側壁 : } 5 \\
\text { 翼口蓋窩 : } 3 \text {, 他 }\end{array}$ & $\begin{array}{l}\text { 副鼻腔 : } 21 \\
\text { 鼻腔側壁 : } 2 \\
\text { 鼻中隔 : } 2 \text {, 他 }\end{array}$ & $\begin{array}{l}\text { 副鼻腔 : } 36 \\
\text { 眼窩 : } 4 \\
\text { 鼻中隔 : } 4 \text {, 他 }\end{array}$ \\
\hline
\end{tabular}

者の生命に危険を及ぼさず，機能的障害を起乙 さぬ範囲内で除去に努力したほうがよいと述べ ている。また森川らは異物は体内にあることは 不自然な状態であり摘出を行うことが妥当であ ろうと述べている。

異物の摘出の適応を論ずるうえでその組成を 知ることは非常に重要であるが一般的な検査デ 一タからその情報を得るのは難しく，結局摘出 後に知ることが多( ${ }^{4) 5}$. 体内に入った金属は, 被膜で覆われること，異物として作用し新生組 織に取り囲まれ極めて吸収されにくい状態にな り，中毒症状を呈することは稀であるとされて (る ${ }^{677)}$. しかし前述の受傷後 21 年経て発症し た城所らの例，武内らの両下肢切断を要した症 例8)なよ゙本邦でも異物による鉛中毒も報告され 軽視はできない。いずれにせよ鉛中毒が確認さ れた場合，今回のように感染を伴った場合は摘 出の絶対適応と考えられる.

\section{結語}

戦時下に空爆の破片による耳後部異物が殆ど 無症状で約40年間滞留した例を報告した.

尚, 本論文の要旨は日耳鼻東京都地方会第61回学術 講演会にて発表しました。

\section{参考文献}

1）城所信五郎, 石井英雄, 井上 正 : 耳鼻科領域に 扣ける空気銃弾射入の 4 症例. 耳喉 29:885〜 887, 1957.

2) 森満 保，坂本 守：翼口蓋窩異物症(空気銃弾) の一例. 耳鼻 $8: 279 \sim 283,1962$.

3 ）太田良夫, 村上 陸 : 節骨洞及び鼻中隔異物（発 気銃弾）の 2 症例. 耳喉 $35: 397 \sim 401,1963$.

4 ）森川郁郎, 進 武幹, 富田まり子：39年間頸部に 存在した砲弾片異物の 1 例. 耳喉 $57: 7 ; 583$ 587, 1985.

5 ) 岡田芳明, 藤井千穂, 島崎修次 : 鉛銃弾遺残症例 の検討. 外科治療 $32 ： 6 ； 642 \sim 644,1975$.

6) Willard M : Lead absorption from bullets lodged in tissues. JAMA $115:$ 1536 1541, 1940.

7) Friedrich B : Ueber die Giftwirkung der Blei- 
Steckschüsse. Beith Z Klin Chir $126: 324 \sim 335$, 1922.

8) 武内 惇, 宮坂 裕, 沼田一: 両下肢切断を要 した鉛中毒の 1 例. 整形外科 $20: 744 \sim 748$, 1969.
(原稿採択 : 平成元年 6 月 1 日

別刷請求先 : 斎藤秀樹

干113 東京都文京区本郷2-1-1

順天堂大学医学部耳鼻咽喉科学教室 